\title{
Recovery of n-3 polyunsaturated fatty acids and conjugated linoleic acids in ripened cheese obtained from milk of cows fed different levels of extruded flaxseed
}

\author{
M. Cattani, ${ }^{, 1}$ R. Mantovani, $\uparrow$ S. Schiavon, $\nmid$ G. Bittante, $\nmid$ and L. Bailoni ${ }^{*}$ \\ *Department of Comparative Biomedicine and Food Science (BCA), University of Padova, Viale dell'Università 16, 35020, Legnaro (PD), Italy \\ †Department of Agronomy, Food, Natural Resources, Animals and Environment (DAFNAE), University of Padova, Viale dell'Università 16, 35020, \\ Legnaro (PD), Italy
}

\begin{abstract}
The aim of the study was to investigate whether the addition of extruded flaxseed (EF) in dairy cow diets had an effect on milk fat and individual fatty acids (FA) recovery in cheese after $90 \mathrm{~d}$ of ripening. Eighteen Holstein-Friesian cows, divided into 3 experimental groups (6 cows/group), were fed 3 isonitrogenous and isoenergetic diets with 0 (CTR), 500 (EF500), or 1,000 $\mathrm{g} / \mathrm{d}$ (EF1000) of EF in 3 subsequent periods (2 wk/ each), following a $3 \times 3$ Latin square design. Dry matter intake (DMI) and milk yield were recorded daily. Individual milk samples were collected on d 7 and 13 of each period to determine proximate and FA composition. Eighteen cheese-making sessions (2 for each group and period) were carried out, using a representative pooled milk sample obtained from the 6 cows of each group (10 L). At $90 \mathrm{~d}$ of ripening, cheeses were analyzed for proximate and FA composition. Cheese yield was computed as the ratio between the weights of ripened cheese and processed milk. Recoveries of fat, individual FA, and grouped FA were computed as the ratio between the corresponding weights in cheese and in milk. Inclusion of EF did not affect DMI, milk yield, or milk composition. Compared with CTR, the 2 diets containing EF increased the proportion of C18:3n-3 and total n-3 FA, in both milk and cheese. Cheese yield and cheese fat percentage did not differ among diets. Likewise, milk fat recovery in cheese was comparable in the 3 treatments and averaged 0.85 . The recoveries of individual FA were, for the most part, not dissimilar from fat recovery, except for short-chain saturated FA (from 0.38 for C4:0 to 0.80 for C13:0), some long-chain saturated FA (0.56 and 0.62 for C20:0 and C21:0, respectively), and for C18:3n-6 (1.65). The recovery of saturated FA was lower than that of monounsaturated FA, whereas recovery of polyunsaturated FA was inter-
\end{abstract}

Received July 1, 2013.

Accepted October 7, 2013.

${ }^{1}$ Corresponding author: mirko.cattani@unipd.it mediate. Compared with medium- and long-chain FA, short-chain FA were recovered to a smaller extent in cheese. No differences in recovery were found between n-6 and n-3 FA. In conclusion, FA have different recoveries during cheese-making, with lower values for the short-chain compared with long-chain FA, and for saturated FA compared with unsaturated FA. The addition of EF in dairy cow diets did not influence cheese yield or fat recovery in cheese, irrespective of the inclusion level. The experiment confirmed that feeding cows with EF represents a successful strategy for improving the FA profile of dairy products, through an increase of n-3 FA.

Key words: extruded flaxseed, cheese yield, fatty acid recovery, dairy cow

\section{INTRODUCTION}

The efficiency of the cheese-making process is defined as the proportion of milk constituents (i.e., protein and fat) that are recovered in the curd or lost in the whey (Banks, 2007). However, the recovery of individual protein fractions and FA can also influence the perceived quality and effect of cheese on human health. The literature indicates that the efficiency of the cheesemaking process is influenced by factors directly related to animals, such as species (Zicarelli et al., 2007), breed (Martin et al., 2009), parity and stage of lactation (Cipolat-Gotet et al., 2013), and health status (Politis and Ng-Kwai-Hang, 1988). Moreover, factors related to milk composition (Bittante et al., 2012) and adopted production technology (Lucey and Kelly, 1994) can influence the cheese-making process. Together with these factors, the feeding regimen of cows seems to play a primary role in determining the suitability of milk for cheese-making and the level of efficiency at which milk protein and fat are transferred into cheese (Banks et al., 1986).

In recent years, several experiments conducted on dairy cows have highlighted that a supplementation of oilseeds rich in n-3 FA, such as flaxseed, rapeseed, 
or soybean, is an effective strategy for improving the nutritional value of milk fat (Shingfield et al., 2008), which is otherwise relatively poor in these FA (Bailoni et al., 2005). Furthermore, some studies have shown that these oilseeds can be offered to dairy ewes to improve the FA profile of cheese produced by processing their milk (Luna et al., 2005; Nudda et al., 2006; Gómez-Cortés et al., 2009; Mele et al., 2011). However, there is a scarcity of knowledge on the possible effects of these oilseeds on the FA profile of cheese produced using bovine milk. No attempts have been made to investigate if oilseed supplementation may affect the passage of different constituents, and especially of individual FA, from bovine milk to cheese. Thus, the present study aimed to investigate the possible effects of different inclusion levels of extruded flaxseed (EF) on (1) milk yield and quality, and (2) individual FA recovery in ripened cheese.

\section{MATERIALS AND METHODS}

\section{Animals, Experimental Design, and Diets}

All experimental procedures were carried out according to Italian law on animal care (Legislative Decree No. 116 of January 27, 1992). Eighteen Holstein-Friesian dairy cows, housed at the Experimental Farm of the University of Padova (Legnaro, Italy), were assigned, 1 wk before the beginning of the experiment to 3 experimental groups in a $3 \times 3$ Latin square design ( 6 cows per group), balanced for DIM (108 $\pm 48.3 \mathrm{~d})$, parity $(1.6 \pm 0.92)$, and milk yield $(35.5 \pm 9.25 \mathrm{~kg} / \mathrm{d})$. Each group received a basal TMR, an individual mixture of concentrate (Table 1), and an individual supplement with 0 (CTR), 500 (EF500), or 1,000 (EF1000) g/d of EF (Linoies, Cortal Extrasoy, Cittadella, Italy). The TMR was composed of feed ingredients commonly used in the dairy farms of northern Italy, and the composition was defined to meet the nutritional requirements (NRC, 2001) of cows producing $25 \mathrm{~kg} / \mathrm{d}$ of milk. The additional requirements for milk yield $>25 \mathrm{~kg} / \mathrm{d}$ were guaranteed by an individual offering of concentrates (mixture of corn meal and soybean meal) using automatic feeders. The 3 experimental supplements were formulated to be isoenergetic and isonitrogenous by using different amounts of EF, soybean meal, and calcium soaps of palm (Table 2). The supplementations were offered daily to each cow in an individual manger until their complete consumption before TMR distribution. The whole trial lasted $65 \mathrm{~d}$ and included a 9-d diet adjustment period, 3 experimental periods (14 d/each) during which the cows received the 3 experimental diets, and 2 transition periods $(7 \mathrm{~d} /$ each) during which the cows were fed only the basal TMR and the individual
Table 1. Ingredients and chemical composition of the basal diet ${ }^{1}$

\begin{tabular}{|c|c|}
\hline \multicolumn{2}{|l|}{ Basal diet } \\
\hline \multicolumn{2}{|l|}{ Ingredients, $\%$ of DM } \\
\hline Corn silage & 33.1 \\
\hline Wheat bran & 12.5 \\
\hline Meadow hay & 12.4 \\
\hline Barley meal & 11.0 \\
\hline Alfalfa hay & 9.5 \\
\hline Corn meal & 7.1 \\
\hline Soybean meal, $48 \%$ CP & 5.5 \\
\hline Dry sugar beet pulp & 3.1 \\
\hline Calcium soaps of palm ${ }^{2}$ & 2.9 \\
\hline Vitamin and mineral premix ${ }^{3}$ & 2.9 \\
\hline \multicolumn{2}{|l|}{ Chemical composition, \% of $\mathrm{DM}^{4}$} \\
\hline DM, $\%$ as fed & 51.8 \\
\hline OM & 93.9 \\
\hline $\mathrm{CP}$ & 13.7 \\
\hline Lipids & 5.1 \\
\hline NDF & 37.6 \\
\hline Starch & 22.9 \\
\hline $\mathrm{NSC}^{5}$ & 37.4 \\
\hline $\mathrm{NE}_{\mathrm{L}},{ }^{6} \mathrm{MJ} / \mathrm{kg}$ & 7.99 \\
\hline \multicolumn{2}{|c|}{$\begin{array}{l}{ }^{1} \mathrm{TMR} \text { plus concentrate supplementation provided by automatic auto- } \\
\text { feeder. }\end{array}$} \\
\hline \multicolumn{2}{|c|}{ ²Magnapac (Norel, Animal Nutrition, Madrid, Spain). } \\
\hline \multicolumn{2}{|c|}{$\begin{array}{l}{ }^{3} \text { Quality Index Complete (Farmer Spa, Porto Mantovano, Mantova, } \\
\text { Italy), contained per kilogram: } 240,000 \mathrm{IU} \text { of vitamin A, } 500 \mathrm{mg} \text { of } \\
\text { vitamin E, } 80 \mathrm{mg} \text { of vitamin } \mathrm{B}_{1}, 0.4 \mathrm{mg} \text { of vitamin } \mathrm{B}_{12}, 2,040 \mathrm{mg} \text { of } \\
\text { vitamin PP, } 650 \mathrm{mg} \text { of Mn, } 100 \mathrm{mg} \text { of copper (as copper sulfate pen- } \\
\text { tahydrate), } 12 \mathrm{mg} \text { of Co (as basic cobalt carbonate, monohydrate). }\end{array}$} \\
\hline \multicolumn{2}{|c|}{${ }^{4}$ Value obtained by adding $6 \mathrm{~kg}$ of water to the TMR. } \\
\hline \multicolumn{2}{|c|}{${ }^{5}$ Calculated as $100-(\mathrm{CP}+$ lipids + ash $+\mathrm{NDF})$} \\
\hline${ }^{6}$ Computed according to NRC $(2$ & \\
\hline
\end{tabular}

mixture of concentrate. During the trial, cows had free access to water and were fed once daily. The amount of TMR distributed in the manger of each experimental group was measured daily and recorded by the weighing station of the mixer wagon. The orts were collected daily and DMI was computed from TMR consumption and orts on a group basis by adding the amounts of the cereal-soybean mixture and the experimental supplement consumed by each cow.

Cows were milked twice a day (at 0530 and $1730 \mathrm{~h}$ ). All feeds were analyzed in triplicate for DM (method 934.01; AOAC International, 2003), CP (method 976.05; AOAC International, 2003), lipids (method 920.29; AOAC International, 2003), and ash (method 942.05; AOAC International, 2003). The NDF content was measured (Mertens, 2002) with a treatment with $\alpha$-amylase and sodium sulfite using the Ankom ${ }^{220}$ Fiber Analyzer (Ankom Technology Corp., Macedon, NY). Starch was analyzed by HPLC (Bouchard et al., 1988).

\section{Milk Yield and Composition}

Individual milk yield was recorded at each milking using an automatic milking system for a herringbone 
Table 2. Amounts, nutrient supply, and fatty acid profile of supplementations containing increasing amounts of extruded flaxseed

\begin{tabular}{|c|c|c|c|}
\hline \multirow[b]{2}{*}{ Item } & \multicolumn{3}{|c|}{ Dietary treatment ${ }^{1}$} \\
\hline & CTR & EF500 & EF1000 \\
\hline \multicolumn{4}{|l|}{ Supplements, g/d } \\
\hline Extruded flaxseed & - & 500 & 1,000 \\
\hline Soybean meal, $48 \%$ CP & 495 & 248 & - \\
\hline Calcium soaps of palm ${ }^{2}$ & 389 & 194 & - \\
\hline \multicolumn{4}{|c|}{ Nutrient supply, g/d per cow } \\
\hline $\mathrm{DM}$ & 819 & 877 & 935 \\
\hline $\mathrm{OM}$ & 729 & 811 & 893 \\
\hline $\mathrm{CP}$ & 238 & 238 & 238 \\
\hline Lipids & 340 & 376 & 412 \\
\hline NDF & 34 & 44 & 54 \\
\hline Starch & 28 & 14 & 0 \\
\hline $\mathrm{NSC}^{3}$ & 182 & 218 & 254 \\
\hline $\mathrm{NE}_{\mathrm{L}},{ }^{4} \mathrm{MJ} / \mathrm{d}$ & 10.4 & 11.3 & 12.6 \\
\hline \multicolumn{4}{|l|}{ Fatty acids, g/d per cow } \\
\hline C16:0 & 147 & 86 & 25 \\
\hline C18:0 & 17 & 22 & 27 \\
\hline C18:1 & 134 & 108 & 82 \\
\hline $\mathrm{C} 18: 2 \mathrm{n}-6$ & 36 & 55 & 75 \\
\hline C18:3n-3 & 1 & 98 & 196 \\
\hline
\end{tabular}

parlor coupled with automatic recording software (Alpro, DeLaval, Tumba, Sweden). On d 7 and 13 of each experimental period, milk samples (3 L) from the morning milking were collected from each cow to be analyzed for proximate composition, FA profile, and cheese manufacturing properties. An aliquot $(50 \mathrm{~mL})$ of milk was frozen and stored at $-20^{\circ} \mathrm{C}$ for $\mathrm{FA}$ assessment, whereas a second aliquot $(50 \mathrm{~mL})$ was preserved with bronopol-B2 at $4^{\circ} \mathrm{C}$. The latter milk sample was analyzed for fat, protein, and lactose contents using the FILIDF procedure (International Dairy Federation, 2000) and the Milko-Scan apparatus (Foss Electric, Hillerød, Denmark). Milk urea nitrogen was measured automatically by the conduct metric-enzymatic method (CL 10 micro analyzer, Eurochem, Roma, Italy). Somatic cell count was performed using a Bentley Somacount 150 (Bentley, Chaska, MN) according to the FIL-IDF148a standard (International Dairy Federation, 1995), and transformed in logarithmic terms using the following equation: $\operatorname{SCS}=3+\ln _{2}\left(\mathrm{SCC} \times 10^{-5}\right)$. Milk fat was extracted by accelerated solvent extraction (ASE 200, Dionex Corp., Sunnyvale, CA) using petroleum ether:isopropanol $(3: 2 \mathrm{vol} / \mathrm{vol})$, and the extracted fat was analyzed for FA composition.

Milk FA were transesterified according to the procedure of Christie (1982) with modifications proposed by Chouinard et al. (1999). Briefly, a solution (1:1) of hexane and internal standard (nonadecanoic acid methyl ester C19:0) was added to $40 \mathrm{mg}$ of butter oil followed by $100 \mu \mathrm{L}$ of methyl acetate. The mixture was vortexed and $100 \mu \mathrm{L}$ of methylation reagent ( $1 M$ methoxy in methanol) was added and allowed to react for $15 \mathrm{~min}$. Thereafter, $150 \mu \mathrm{L}$ of termination reagent ( $1 \mathrm{~g}$ of oxalic acid/30 mL of ethyl ether) was added. Samples were centrifuged for $5 \mathrm{~min}$ at $2,400 \times g$ at $5^{\circ} \mathrm{C}$, leaving a clear layer of hexane; an aliquot of hexane was taken and used directly for chromatographic analysis. Fatty acid methyl esters were separated using a GC 8000 Top Series gas chromatograph (CE Instruments, Wigan, UK) equipped with a $40 \mathrm{~m} \times 0.18 \mathrm{~mm}$ (i.d.) RTX-2330 column (Restek Corp., Bellefonte, PA). The carrier gas was hydrogen, with a flow of $1.60 \mathrm{~mL} / \mathrm{min}$ and a linear speed of $40.2 \mathrm{~cm} / \mathrm{s}$. Oven temperature was set at $50^{\circ} \mathrm{C}$ for $1 \mathrm{~min}$, and then increased to $100^{\circ} \mathrm{C}$ at $50^{\circ} \mathrm{C} / \mathrm{min}$. The temperature was then increased at $150^{\circ} \mathrm{C}$ at $3^{\circ} \mathrm{C} /$ min and let stand for $1 \mathrm{~min}$, and finally increased to $220^{\circ} \mathrm{C}$ at $2^{\circ} \mathrm{C} / \mathrm{min}$. Injector (split rate $=80 \mathrm{~mL} / \mathrm{min}$ ) and detector were maintained at $250^{\circ} \mathrm{C}$.

\section{Cheese Making}

Milk from the morning milking collected on $\mathrm{d} 7$ and 13 of each experimental period was used for cheese making, without preliminary pasteurization or homogenization treatments. The cheese-making procedure has been described in previous studies (Cologna et al., 2009; 
Cipolat-Gotet et al., 2013), but in this case, 3 laboratory cheese vats of 11-L capacity (Pierre Guerin Technologies, Mauze, France) were used. A pooled sample of milk (10 L) obtained from the 6 cows of each group was added to each vat so that cheese-making was carried out simultaneously for the 3 experimental treatments. Milk was slowly heated to $32^{\circ} \mathrm{C}$ by water circulation in a heating jacket using a water bath (model SB24, Falc Instrument, Treviglio, Italy). Once milk reached $32^{\circ} \mathrm{C}$, starter cultures of freeze-dried mesophilic lactic bacteria (LL50 X, DSM Food Specialties, Delft, the Netherlands) were added to the milk. After acidification $\left(32^{\circ} \mathrm{C}\right.$ for $45 \mathrm{~min}$ ), a water solution of $4 \mathrm{~mL}$ of commercial liquid rennet Camoscio 105/75 (DSM Food Specialties, Segrate, Italy) with a 75:25 ratio between chymosin and pepsin and 105 international milk clotting units $(\mathrm{IMCU}) / \mathrm{mL}$ was added to each vat $(42.0 \mathrm{IMCU} / \mathrm{L}$ of milk). Continuous monitoring of milk coagulation and curd syneresis was performed directly on each vat using a CoAguLite sensor (Reflectronics Inc., Lexington, KY; Fagan et al., 2007). The sensor allowed the selection of the cutting time (4 min after the CoAguLite's R signal). Following the syneresis phase, curd was extracted from each vat and portioned into 3 cheese molds, pressed, and immersed in a brine solution $(20 \%$ of $\mathrm{NaCl}$ for $4 \mathrm{~h}$ ). Finally, the cheeses were stored in the ripening cell for $90 \mathrm{~d}$ at $15^{\circ} \mathrm{C}$ and $85 \%$ relative humidity. The cheese wheels obtained in different cheese-making sessions were weighed after 1 and $90 \mathrm{~d}$. The methods for extraction of cheese fat and analysis of FA profile were the same as described for milk fat.

\section{Computations}

The studied traits were based on the weights and chemical compositions of the milk, and curd. The classical formula for cheese yield $\left(\mathbf{C Y}_{\mathbf{C U R D}}, \%\right)$ can be written as follows:

$$
\mathrm{CY}_{\mathrm{CURD}}=\frac{\text { Weight of curd }(\mathrm{g})}{\text { Weight of milk }(\mathrm{g})} \times 100 \text {. }
$$

Curd was weighed after brining. Considering the weight $(\mathrm{g})$ of fat in the milk and cheese after $90 \mathrm{~d}$ of ripening, recovery of fat in the cheese $\left(\mathbf{R E C} \mathbf{C}_{\mathbf{F A T}}\right)$ was calculated as follows:

$$
\mathrm{REC}_{\mathrm{FAT}}=\frac{\text { Cheese fat }(\mathrm{g})}{\text { Milk fat }(\mathrm{g})} .
$$

The recoveries of individual FA $\left[\mathbf{R E C}_{\mathbf{i}(\mathbf{F A})}\right]$ or grouped FA were based on FA profile of milk and cheese, expressed as weight $(\mathrm{g})$ of individual or grouped FA per $100 \mathrm{~g}$ of FA, and were calculated as follows:

$$
\mathrm{REC}_{\mathrm{i}(\mathrm{FA})}=\frac{\text { Cheese fatty acid }}{\text { Milk fatty acid }} \times \mathrm{REC}_{\mathrm{FAT}} .
$$

\section{Statistical Analysis}

All group data (DMI, cheese yield and composition, cheese FA profile, fat recovery) were analyzed as a $3 \times$ 3 Latin square design using PROC GLM (SAS Institute, 2005) according to the following linear model:

$$
\mathrm{y}_{\mathrm{ijkl}}=\mu+\mathrm{T}_{\mathrm{i}}+\mathrm{P}_{\mathrm{j}}+\mathrm{G}_{\mathrm{k}}+\varepsilon_{\mathrm{ijkl}}
$$

where $y_{\mathrm{ijkl}}=$ single observation referred to the experimental unit; $\mu=$ overall mean; $T_{i}=$ effect of dietary treatment $(\mathrm{i}=3$ levels $) ; \mathrm{P}_{\mathrm{j}}=$ effect of period $(\mathrm{j}=3$ levels); $\mathrm{G}_{\mathrm{k}}=$ effect of the group of cows ( $\mathrm{k}=3$ levels); and $\varepsilon_{\mathrm{ijkl}}=$ residual error term $\sim N\left(0, \sigma_{e}^{2}\right)$.

All data obtained on individual animals (6 cows per group) and repeated over time (milk yield, milk composition, and milk FA profile) were averaged by group, which was considered as the experimental unit and analyzed using the model previously described.

The recoveries of each individual $\mathrm{FA}, \mathrm{REC}_{\mathrm{i}(\mathrm{FA})}$, and grouped FA were analyzed with model [1], considering the recovery of $\mathrm{fa}=\mathrm{t}$ as a linear covariate. Therefore, the final model was

$$
\mathrm{y}_{\mathrm{ijkl}}=\mu+\mathrm{T}_{\mathrm{i}}+\mathrm{P}_{\mathrm{j}}+\mathrm{G}_{\mathrm{k}}+\mathrm{bX}_{\mathrm{ijkl}}+\varepsilon_{\mathrm{ijkl}},
$$

where $\mathrm{y}_{\mathrm{ijkl}}$ is the observed recovery of an individual FA or grouped FA and, with respect to model [1], $\mathrm{b}$ is the linear regression coefficient and $\mathrm{X}_{\mathrm{ijkl}}$ is $\mathrm{REC}_{\mathrm{FAT}}$ in each experimental unit.

To obtain a comparison among the average individual $\mathrm{REC}_{\mathrm{i}(\mathrm{FA})}$, the measured $\mathrm{REC}_{\mathrm{i}(\mathrm{FA})}$ were analyzed together and the classical $3 \times 3$ Latin square design was expanded to include the effect of FA in the model:

$\mathrm{y}_{\mathrm{ijklm}}=\mu+\mathrm{T}_{\mathrm{i}}+\mathrm{P}_{\mathrm{j}}+\mathrm{G}_{\mathrm{k}}+\mathrm{FA}_{1}+(\mathrm{T} \times \mathrm{FA})_{\mathrm{il}}+\varepsilon_{\mathrm{ijklm}}$,

where, with respect to model [1], $\mathrm{FA}_{1}$ is the class of single FA (i.e., from $\mathrm{C} 4: 0$ to $\mathrm{C} 20: 5 \mathrm{n}-3)$ and $(\mathrm{T} \times \mathrm{FA})_{\text {il }}$ is the interaction between dietary treatment and class of single FA. Similar models were used to compare the recoveries of SFA, MUFA, and PUFA, of short-, medium-, and long-chain FA, and of n-3 and n- 6 FA.

All results are presented as least squares means \pm SEM. Orthogonal contrasts were run to analyze the statistical differences of CTR versus (EF500 + EF1000)/2 and of EF500 versus EF1000. Statistical significance was declared at $P \leq 0.05$ and a tendency at $0.05<P$ $\leq 0.10$. 
Table 3. Least squares means \pm SEM of DMI, milk yield and composition, and cheese yield in 3 dietary treatments (CTR, EF500, and EF1000 $=0,500$, or $1,000 \mathrm{~g} / \mathrm{d}$ of extruded flaxseed, respectively)

\begin{tabular}{|c|c|c|c|c|c|c|}
\hline \multirow[b]{2}{*}{ Item } & \multicolumn{3}{|c|}{ Dietary treatment } & \multirow[b]{2}{*}{ SEM } & \multicolumn{2}{|c|}{$P$-value } \\
\hline & CTR & EF500 & EF1000 & & $\begin{array}{c}\text { CTR } \\
\text { vs. } \mathrm{EF}^{1}\end{array}$ & $\begin{array}{c}\text { EF500 } \\
\text { vs. EF1000 }\end{array}$ \\
\hline DMI, $\mathrm{kg} / \mathrm{d}$ & 19.0 & 19.4 & 19.4 & 0.420 & 0.52 & 0.98 \\
\hline \multicolumn{7}{|l|}{ Yield, $\mathrm{kg} / \mathrm{d}$} \\
\hline Milk & 29.1 & 29.3 & 27.9 & 0.440 & 0.48 & 0.15 \\
\hline FCM & 27.9 & 27.7 & 26.6 & 0.920 & 0.59 & 0.50 \\
\hline Lactose & 1.41 & 1.42 & 1.38 & 0.030 & 0.76 & 0.44 \\
\hline \multicolumn{7}{|c|}{ Milk composition, \% } \\
\hline Fat & 3.64 & 3.49 & 3.46 & 0.159 & 0.49 & 0.93 \\
\hline Protein & 3.40 & 3.45 & 3.44 & 0.069 & 0.66 & 0.91 \\
\hline Lactose & 4.76 & 4.75 & 4.77 & 0.023 & 0.93 & 0.62 \\
\hline Urea, mg/dL & 23.8 & 26.2 & 23.5 & 1.230 & 0.55 & 0.27 \\
\hline SCS, ${ }^{3}$ units & 2.66 & 2.64 & 2.56 & 0.212 & 0.84 & 0.82 \\
\hline
\end{tabular}

${ }^{1}$ CTR vs. (EF500 + EF1000).

${ }^{3} \mathrm{SCS}=3+\ln _{2}(\mathrm{SCC} / 100,000)$.

\section{RESULTS}

\section{DMI, Milk Yield, and Composition}

No differences were detected in DMI, milk yield, or composition among the 3 dietary treatments (Table 3 ). On average, DMI of cows was $19.3 \mathrm{~kg} / \mathrm{d}$. Milk yield and milk fat and protein contents averaged $28.7 \mathrm{~kg} / \mathrm{d}$, $3.53 \%$, and $3.43 \%$, respectively. Lactose (on average $4.76 \%$ ) and urea (on average $24.5 \mathrm{mg} / \mathrm{dL}$ ) contents and SCS (on average 2.62, corresponding to about 110,000 somatic cells $/ \mathrm{mL}$ ) did not differ among diets.

Cheese yield after brine was, on average, $13.5 \%$, and did not differ among the 3 dietary treatments (Table 3 ). Furthermore, EF did not influence the fat percentage of cheese after $90 \mathrm{~d}$ of ripening, irrespective of the supplementation level (on average $40.5 \%$; data not shown).

\section{FA Profile of Raw Milk}

In general, flaxseed exerted only minimal effects on milk FA profile; the effects were not dose-dependent and tended to decrease at increasing supplementation levels (Table 4). The main groups of FA (SFA, MUFA, and PUFA) did not differ among diets, even if a tendency existed for PUFA to be increased by EF supplementation $(P=0.09)$. Among SFA, the supplementation of EF decreased milk concentration of C16:0 $(P<$ $0.05)$ and tended to increase concentrations of C8:0 $(P$ $=0.07)$ and $\mathrm{C} 18: 0(P=0.09)$. The concentration of MUFA was not affected by experimental diets. Among PUFA, the inclusion of EF did not influence the total n-6 FA concentration of milk (on average $2.84 \%$ of total
FA). As expected, EF increased the milk concentration of C18:3n-3 $(P<0.05)$ and of total n-3 FA $(P<0.05)$. As a consequence, the n-6:n-3 ratio was smaller in the 2 diets containing EF compared with CTR $(P<0.05)$.

\section{Profile and Recovery of FA in Ripened Cheese}

As observed for milk, the largest part of individual FA of cheese was not affected by the dietary inclusion of EF (Table 5). Nonetheless, some FA were influenced by EF supplementation, even in ripened cheese. In particular, C16:0 tended to decrease $(P=0.07)$, whereas C18:0, C18:3n-3, and the sum of n-3 FA tended to increase $(P$ $=0.06$ for all) in the 2 diets supplemented with EF. As a result, the n-6:n-3 ratio was smaller $(P<0.05)$ in ripened cheeses produced using milk of supplemented cows compared with that from CTR cows.

The recovery of fat was, on average, approximately 0.85 , and it did not differ among dietary treatments (Table 6). Recovery was different among individual FA $(P<0.001)$ and ranged from a minimum of 0.38 for C4:0 to a maximum of 1.65 for C18:3n-6 (Figure 1). As a consequence, the recovery of $\mathrm{C} 4: 0$ in cheese was lower $(P<0.05)$ than that of most other FA $(27$ of total of $36 \mathrm{FA}$ ), whereas that of $\mathrm{C} 18: 3 \mathrm{n}-6$ was greater $(P<0.05)$ than that of all other FA, except C18:1 trans n-7 (Table 6). Low levels of recovery were found for other SFA, such as C6:0 (0.52), C20:0 (0.56), C21:0 (0.62), C8:0 (0.63), and C11:0 (0.66) (Figure 1). Thus, recovery of SFA was, on average, lower compared with that of MUFA (0.82 vs. 0.96 for SFA and MUFA, respectively; $P<0.01$ ), whereas PUFA showed an inter- 
Table 4. Least squares means \pm SEM of FA profile of raw milk from cows fed 3 dietary treatments $(\mathrm{CTR}$, EF500, and EF1000 $=0,500$, or $1,000 \mathrm{~g} / \mathrm{d}$ of extruded flaxseed, respectively)

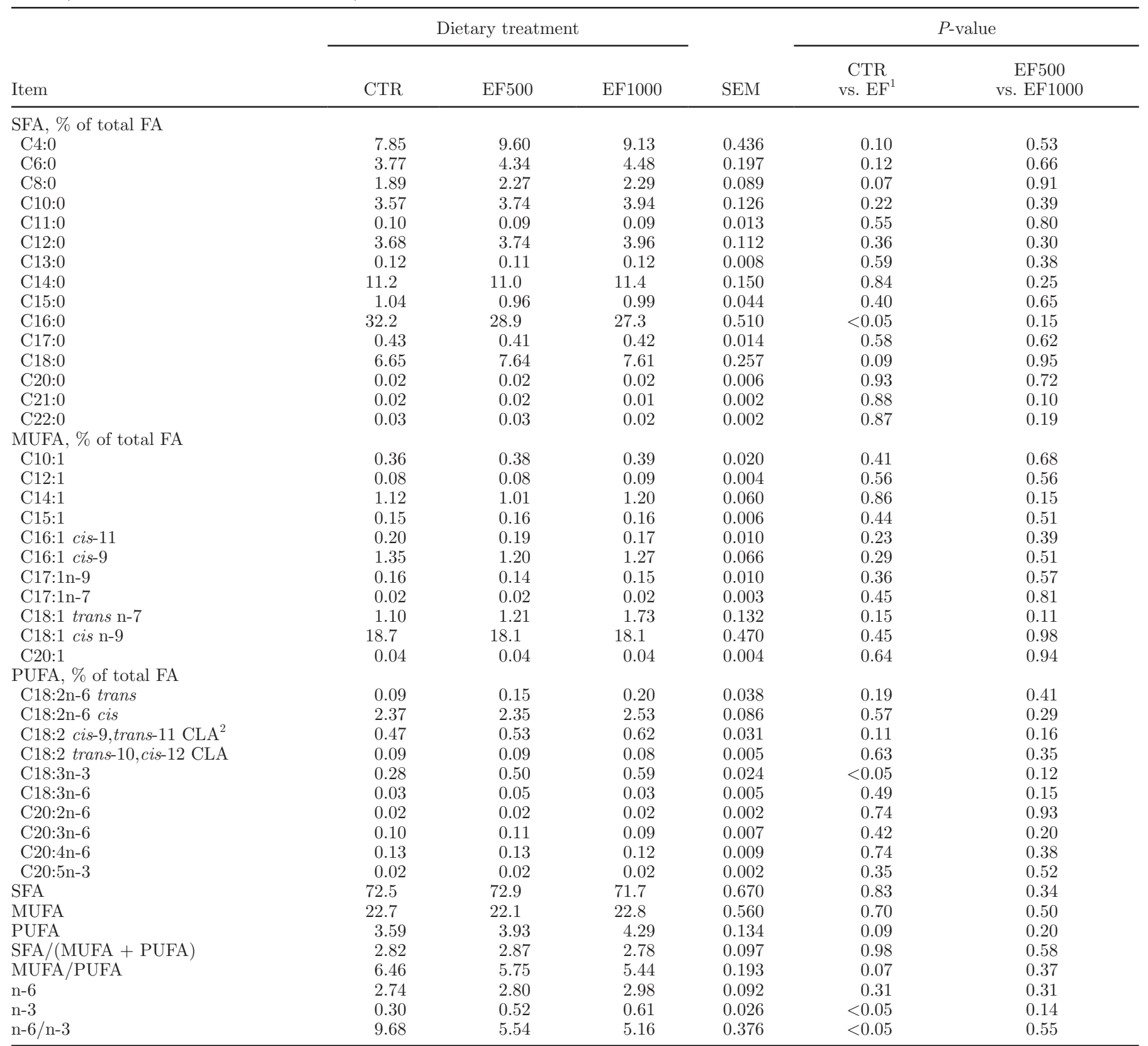

${ }^{1}$ CTR vs. (EF500 + EF1000).

${ }^{2}$ Conjugated linoleic acid.

mediate value (0.89; Figure 2). Likewise, the length of carbon chain had a significant influence on the level of fat recovery, being lower for short-chain FA $(\leq 13$ carbon atoms) compared with medium-chain (from 14 to 17 carbon atoms) and long-chain FA ( $\geq 18$ carbon atoms) (on average, 0.59, 0.93, and 0.94, respectively; $P<0.01$; Figure 3). Conversely, fat recovery did not differ between n- 6 and n-3 FA, irrespective of the diet (Figure 4).

\section{DISCUSSION}

\section{Effect of EF on Milk Yield and Quality and on Cheese Yield}

In agreement with the results of the current experiment, several authors (Kennelly and Khorasani, 1992; Pezzi et al., 2007; Martin et al., 2008) reported that dietary inclusion of flaxseed did not influence the DMI 
Table 5. Least squares means \pm SEM of FA profile of ripened cheese $(90 \mathrm{~d})$ obtained from milk of cows fed 3 dietary treatments (CTR, EF500, and $\mathrm{EF} 1000=0,500$, or $1,000 \mathrm{~g} / \mathrm{d}$ of extruded flaxseed, respectively)

\begin{tabular}{|c|c|c|c|c|c|c|}
\hline \multirow[b]{2}{*}{ Item } & \multicolumn{3}{|c|}{ Dietary treatment } & \multirow[b]{2}{*}{ SEM } & \multicolumn{2}{|c|}{$P$-value } \\
\hline & CTR & EF500 & EF1000 & & $\begin{array}{c}\text { CTR } \\
\text { vs. } \mathrm{EF}^{1}\end{array}$ & $\begin{array}{c}\text { EF500 } \\
\text { vs. EF1000 }\end{array}$ \\
\hline $\mathrm{C} 4: 0$ & 3.62 & 3.84 & 3.81 & 0.134 & 0.35 & 0.89 \\
\hline C6:0 & 2.44 & 2.53 & 2.58 & 0.080 & 0.38 & 0.73 \\
\hline $\mathrm{C} 8: 0$ & 1.57 & 1.57 & 1.60 & 0.063 & 0.85 & 0.76 \\
\hline $\mathrm{C} 12: 0$ & 3.94 & 3.81 & 3.91 & 0.244 & 0.81 & 0.80 \\
\hline C13:0 & 0.12 & 0.10 & 0.11 & 0.008 & 0.30 & 0.82 \\
\hline $\mathrm{C} 14: 0$ & 12.0 & 11.8 & 12.1 & 0.313 & 0.81 & 0.54 \\
\hline C15:0 & 1.06 & 1.03 & 1.03 & 0.045 & 0.65 & 0.95 \\
\hline C16:0 & 35.1 & 32.9 & 31.3 & 0.670 & 0.07 & 0.23 \\
\hline $\mathrm{C} 17: 0$ & 0.47 & 0.45 & 0.44 & 0.020 & 0.41 & 0.88 \\
\hline C18:0 & 7.26 & 8.73 & 8.96 & 0.323 & 0.06 & 0.67 \\
\hline \multicolumn{7}{|l|}{ MUFA, $\%$ of total FA } \\
\hline $\mathrm{C} 12: 1$ & 0.08 & 0.07 & 0.07 & 0.006 & 0.26 & 0.67 \\
\hline C14:1 & 1.10 & 1.00 & 1.14 & 0.053 & 0.73 & 0.22 \\
\hline $\mathrm{C} 15: 1$ & 0.18 & 0.18 & 0.19 & 0.006 & 0.67 & 0.67 \\
\hline $\mathrm{C} 16: 1$ cis-11 & 0.19 & 0.15 & 0.14 & 0.033 & 0.40 & 0.76 \\
\hline $\mathrm{C} 16: 1$ cis-9 & 1.47 & 1.26 & 1.32 & 0.057 & 0.12 & 0.53 \\
\hline C17:1n-9 & 0.03 & 0.02 & 0.04 & 0.016 & 0.79 & 0.42 \\
\hline C17:1n-7 & 0.17 & 0.16 & 0.16 & 0.007 & 0.24 & 0.67 \\
\hline $\mathrm{C} 18: 1$ trans $\mathrm{n}-7$ & 1.36 & 1.60 & 1.82 & 0.132 & 0.16 & 0.36 \\
\hline $\mathrm{C} 18: 1$ cis $\mathrm{n}-9$ & 18.9 & 19.0 & 18.9 & 0.950 & 0.95 & 0.94 \\
\hline $\mathrm{C} 20: 1$ & 0.04 & 0.04 & 0.04 & 0.004 & 0.93 & 0.58 \\
\hline \multicolumn{7}{|l|}{ PUFA, $\%$ of total FA } \\
\hline $\mathrm{C} 18: 2$ trans & 0.08 & 0.12 & 0.10 & 0.021 & 0.36 & 0.65 \\
\hline $\mathrm{C} 18: 2$ cis & 2.40 & 2.45 & 2.61 & 0.076 & 0.32 & 0.28 \\
\hline C18:2 cis-9,trans-11 CLA ${ }^{2}$ & 0.47 & 0.56 & 0.63 & 0.048 & 0.16 & 0.38 \\
\hline PUFA & 3.65 & 4.07 & 4.35 & 0.174 & 0.12 & 0.38 \\
\hline SFA/(MUFA+PUFA) & 2.50 & 2.39 & 2.30 & 0.094 & 0.31 & 0.57 \\
\hline MUFA/PUFA & 6.86 & 6.31 & 6.15 & 0.270 & 0.20 & 0.72 \\
\hline $\mathrm{n}-6$ & 2.79 & 2.88 & 2.98 & 0.076 & 0.26 & 0.47 \\
\hline$n-3$ & 0.31 & 0.53 & 0.64 & 0.055 & 0.06 & 0.30 \\
\hline$n-6 / n-3$ & 9.38 & 5.53 & 4.95 & 0.670 & $<0.05$ & 0.60 \\
\hline
\end{tabular}

${ }^{1}$ CTR vs. (EF500 + EF1000).

${ }^{2}$ Conjugated linoleic acid.

of dairy cows. The short length of the current trial and low amounts of EF included in the diet (about 2.5 and $5.0 \%$ DMI for EF500 and EF1000, respectively) likely explain the lack of effects on milk yield and proximate composition. In this regard, Kim et al. (1991) found that fat supplementation induced changes in protein and fat content of milk after 5 wk or more from the beginning of the supplementation period. Several studies confirmed that flaxseed supplementation did not change either the fat (Gonthier et al., 2005) or the protein concentration of milk (Petit et al., 2004; Martin et al., 2008). Martin et al. (2008) found a depression of milk fat percentage (from 4.11 to $3.53 \%$ ), but this result could be ascribed to huge amounts of EF included in the diet (approximately 15\% of DMI). This may have reduced fiber degradation and acetate production in the rumen, with consequent influences on milk fat synthesis in the udder. Effects of flaxseed 
Table 6. Least squares means \pm SEM of recovery of fat and of individual FA in ripened cheese compared with fat and FA content of milk processed from cows fed 3 dietary treatments (CTR, EF500, and EF1000 $=0$, 500, or 1,000 g/d of extruded flaxseed, respectively) and number of significant differences of mean recovery of each single FA compared with all the others

\begin{tabular}{|c|c|c|c|c|c|c|c|}
\hline Item & \multicolumn{3}{|c|}{ Dietary treatment } & SEM & \multicolumn{2}{|c|}{$P$-value } & $\begin{array}{l}\text { Significant } \\
\text { differences } \\
\text { (no.) }\end{array}$ \\
\hline $\mathrm{C} 4: 0$ & 0.42 & 0.35 & 0.36 & 0.023 & 0.16 & 0.73 & 27 \\
\hline C6:0 & 0.56 & 0.50 & 0.49 & 0.023 & 0.28 & 0.79 & 11 \\
\hline C11:0 & 0.76 & 0.62 & 0.61 & 0.110 & 0.39 & 0.97 & 2 \\
\hline $\mathrm{C} 12: 0$ & 0.91 & 0.88 & 0.83 & 0.049 & 0.47 & 0.58 & 2 \\
\hline C13:0 & 0.84 & 0.81 & 0.75 & 0.069 & 0.53 & 0.63 & 2 \\
\hline C14:0 & 0.91 & 0.90 & 0.90 & 0.021 & 0.66 & 0.96 & 3 \\
\hline C15:0 & 0.87 & 0.91 & 0.88 & 0.023 & 0.49 & 0.53 & 2 \\
\hline C16:0 & 0.92 & 0.96 & 0.98 & 0.011 & 0.08 & 0.49 & 3 \\
\hline C17:0 & 0.93 & 0.91 & 0.89 & 0.033 & 0.56 & 0.73 & 3 \\
\hline \multicolumn{8}{|l|}{ MUFA, $\%$ of total FA } \\
\hline $\mathrm{C} 10: 1$ & 0.80 & 0.76 & 0.72 & 0.059 & 0.53 & 0.66 & 1 \\
\hline $\mathrm{C} 12: 1$ & 0.82 & 0.77 & 0.70 & 0.068 & 0.42 & 0.54 & 1 \\
\hline C14:1 & 0.79 & 0.79 & 0.81 & 0.025 & 0.75 & 0.62 & 2 \\
\hline C15:1 & 0.99 & 1.02 & 1.02 & 0.058 & 0.73 & 1.00 & 2 \\
\hline C16:1 cis-11 & 0.93 & 0.88 & 0.88 & 0.024 & 0.28 & 0.96 & 3 \\
\hline C16:1 cis-9 & 0.81 & 0.75 & 0.74 & 0.063 & 0.54 & 0.91 & 2 \\
\hline C17:1n-9 & 0.90 & 0.90 & 0.87 & 0.035 & 0.77 & 0.59 & 2 \\
\hline $\mathrm{C} 17: 1 \mathrm{n}-7$ & 1.24 & 1.13 & 0.66 & 0.170 & 0.27 & 0.18 & 3 \\
\hline $\mathrm{C} 18: 1$ trans $\mathrm{n}-7$ & 1.06 & 1.21 & 0.88 & 0.118 & 0.92 & 0.20 & 5 \\
\hline $\mathrm{C} 18: 1$ cis $\mathrm{n}-9$ & 0.86 & 0.89 & 0.89 & 0.044 & 0.58 & 0.97 & 2 \\
\hline C20:1 & 0.80 & 0.70 & 0.74 & 0.100 & 0.56 & 0.82 & 1 \\
\hline \multicolumn{8}{|l|}{ PUFA, $\%$ of total FA } \\
\hline $\mathrm{C} 18: 2$ trans & 0.89 & 0.70 & 0.73 & 0.205 & 0.56 & 0.93 & 2 \\
\hline $\mathrm{C} 18: 2$ cis & 0.87 & 0.88 & 0.88 & 0.025 & 0.71 & 0.97 & 2 \\
\hline MUFA & 0.93 & 0.98 & 0.99 & 0.037 & 0.33 & 0.78 & - \\
\hline PUFA & 0.86 & 0.88 & 0.91 & 0.060 & 0.68 & 0.77 & - \\
\hline n-6 & 0.87 & 0.88 & 0.88 & 0.053 & 0.85 & 0.97 & - \\
\hline $\mathrm{n}-3$ & 0.88 & 0.90 & 0.83 & 0.059 & 0.60 & 0.48 & - \\
\hline
\end{tabular}

${ }^{1}$ CTR vs. (EF500 + EF1000).

${ }^{2}$ Conjugated linoleic acid.

on milk protein content seem to be dependent on the physical form of seeds and chemical treatments (i.e., with formaldehyde), which can lead to an increase of milk protein content, by reducing rumen degradation of seeds and, thus, increasing the intestinal availability of AA for synthesis of milk protein (Petit, 2003). In the current experiment, flaxseed was subjected to extrusion, which was found to be less effective than formaldehyde in protecting oilseeds from rumen degradation (Gonthier et al., 2005) and this could explain the unchanged protein content of milk. Flaxseed did not influence the lactose percentage or the SCC of milk, according to the literature (Martin et al., 2008).

In this experiment, cheese yield after brining was very similar to laboratory data reported by VerdierMetz et al. (2001), using milk from 3 breeds, and by Cologna et al. (2009), which processed Holstein milk, whereas Cipolat-Gotet et al. (2013), using Brown Swiss cows, found higher cheese yield (15\%). Cheese-making technology is the most important factor affecting the 


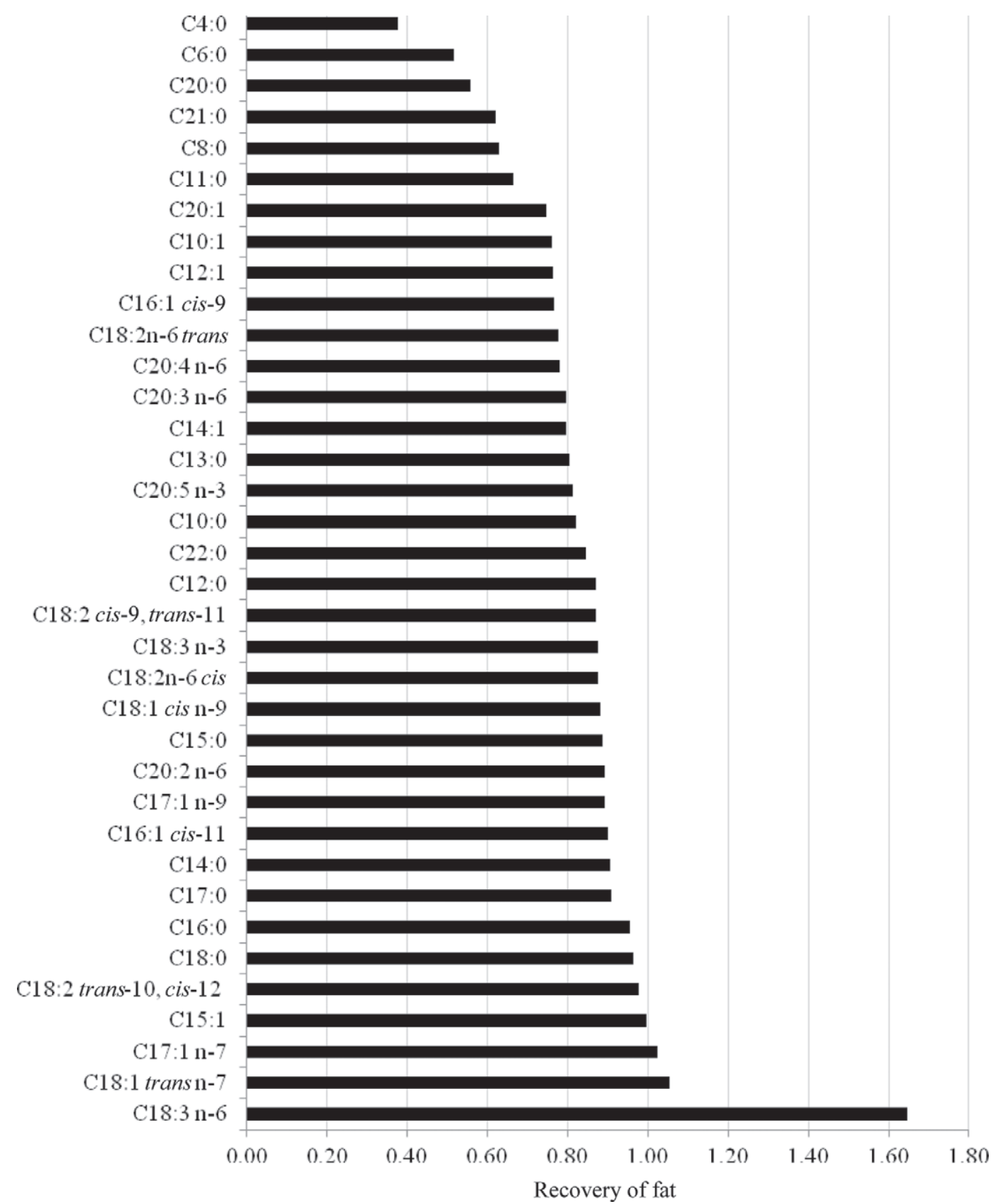

Figure 1. Recovery of individual FA from milk to cheese ripened for $90 \mathrm{~d}$ (the number of significant differences between each FA and the others are reported in Table 6).

efficiency of milk processing (Janhøj and Qvist, 2010), together with physical, chemical, and coagulation properties of milk (Macciotta et al., 2012). Lack of differences in fat content of cheese among diets confirmed the results achieved for the original milk. In this regard, Lucas et al. (2006) reported that the fat content of cheese is primarily influenced by the fat content of original milk and by its ability to be retained in curd (Cipolat-Gotet et al., 2013), even if this phenomenon is partly under genetic control (Bittante et al., 2013). The cheese-making technology is considered to be of minor importance (Gnädig et al., 2004; Lucas et al., 2006).

\section{Effect of EF on FA Profile of Raw Milk}

Genetic type and nutrition of the cow are considered to be the most important factors affecting the FA profile of bovine milk. From a meta-analysis of published 


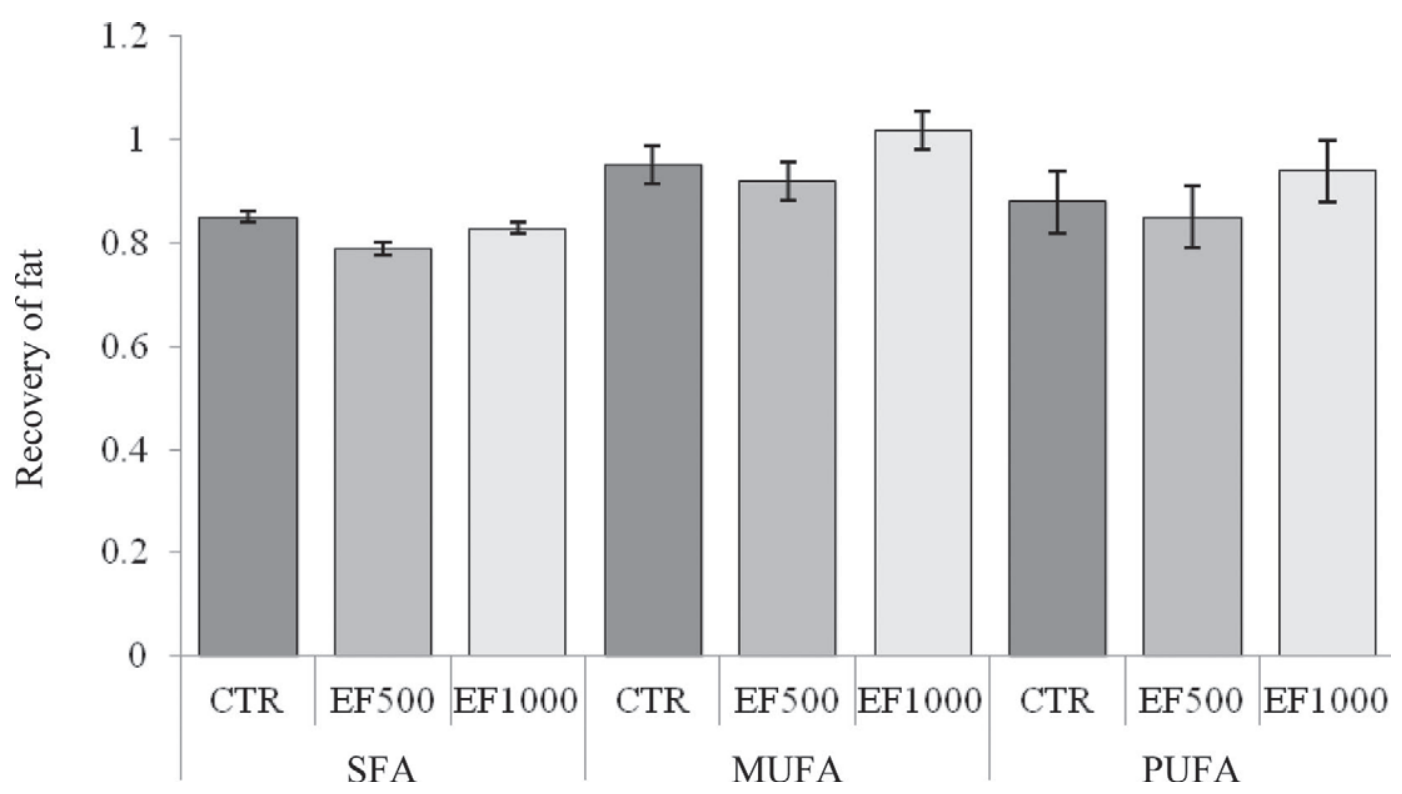

Figure 2. Least squares means (with SE whiskers) of the recovery of SFA, MUFA, and PUFA from milk to ripened cheese (90 d) produced by cows fed the 3 dietary treatments (CTR, EF500, and EF1000 $=0,500$, or 1,000 g/d of extruded flaxseed, respectively). The contrasts between CTR and (EF500 + EF1000) and between EF500 and EF1000 were not significant.

data, Glasser et al. (2008) concluded that flaxseed increases the proportion of n-3 FA in milk, even if these increments in most cases are small, as the content of n-3 FA never exceeds the threshold of $1 \%$ of total FA. Furthermore, the same authors specified that these effects are usually dose-dependent, as positive responses tend to disappear at supplementation levels $>600 \mathrm{~g} / \mathrm{d}$.
Accordingly, in this experiment, the presence of flaxseed in the diet increased the proportion of n-3 FA in milk fat, but this amount remained under $1 \%$ of total FA; furthermore, such a response slightly decreased when EF supplementation increased from 500 to $1,000 \mathrm{~g} / \mathrm{d}$ of the diet. However, an increase of n-3 FA in milk fat, together with a decrease in the ratio between n- 6 and

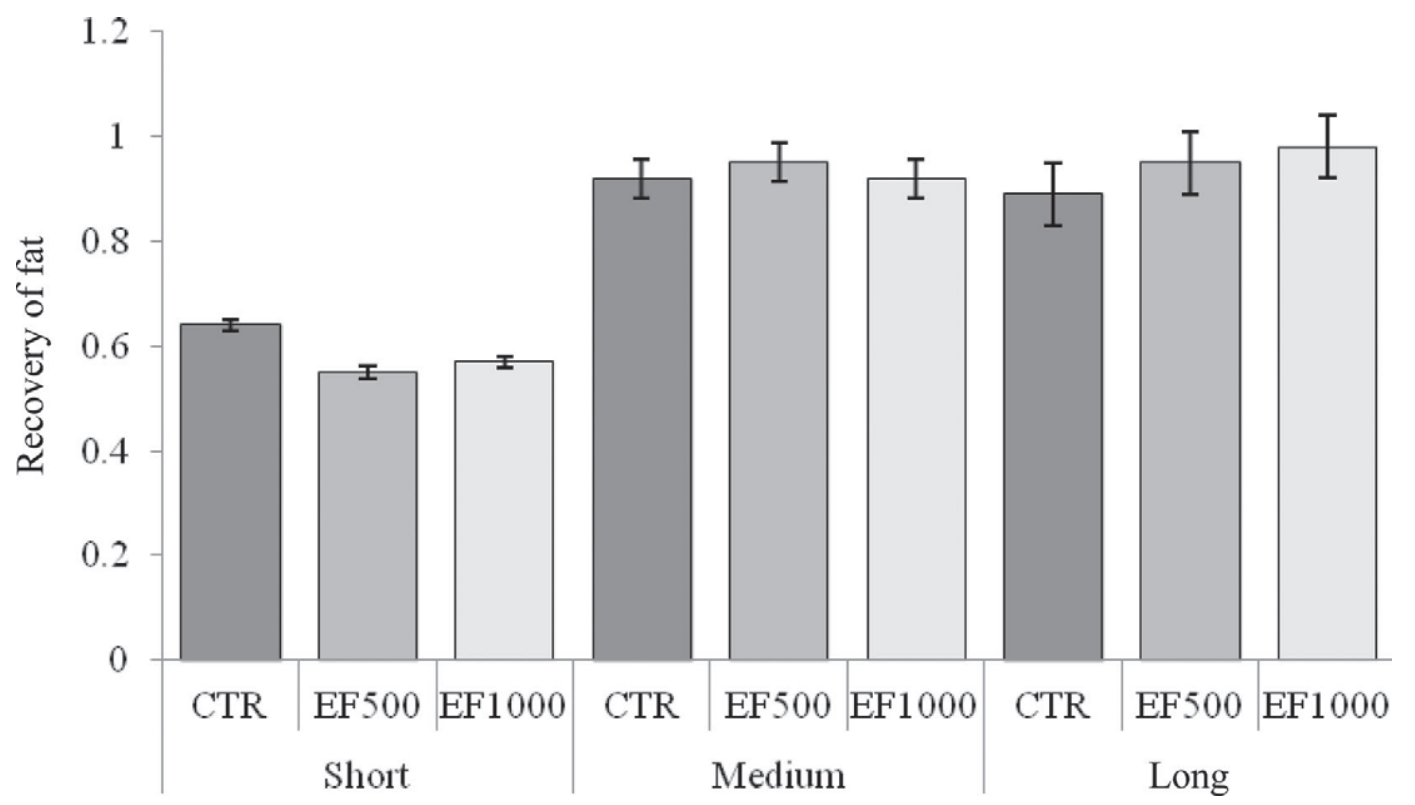

Figure 3. Least squares means (with SE whiskers) of the recovery of short- ( $\leq 13$ carbons), medium- (from 14 to 17 carbons), and long-chain $(\geq 18$ carbons $)$ FA from milk to ripened cheese $(90 \mathrm{~d})$ produced by cows fed the 3 dietary treatments $(\mathrm{CTR}$, EF500, and EF1000 $=0,500$, or $1,000 \mathrm{~g} / \mathrm{d}$ of extruded flaxseed, respectively). The contrasts between CTR and (EF500 + EF1000) and between EF500 and EF1000 were not significant. 


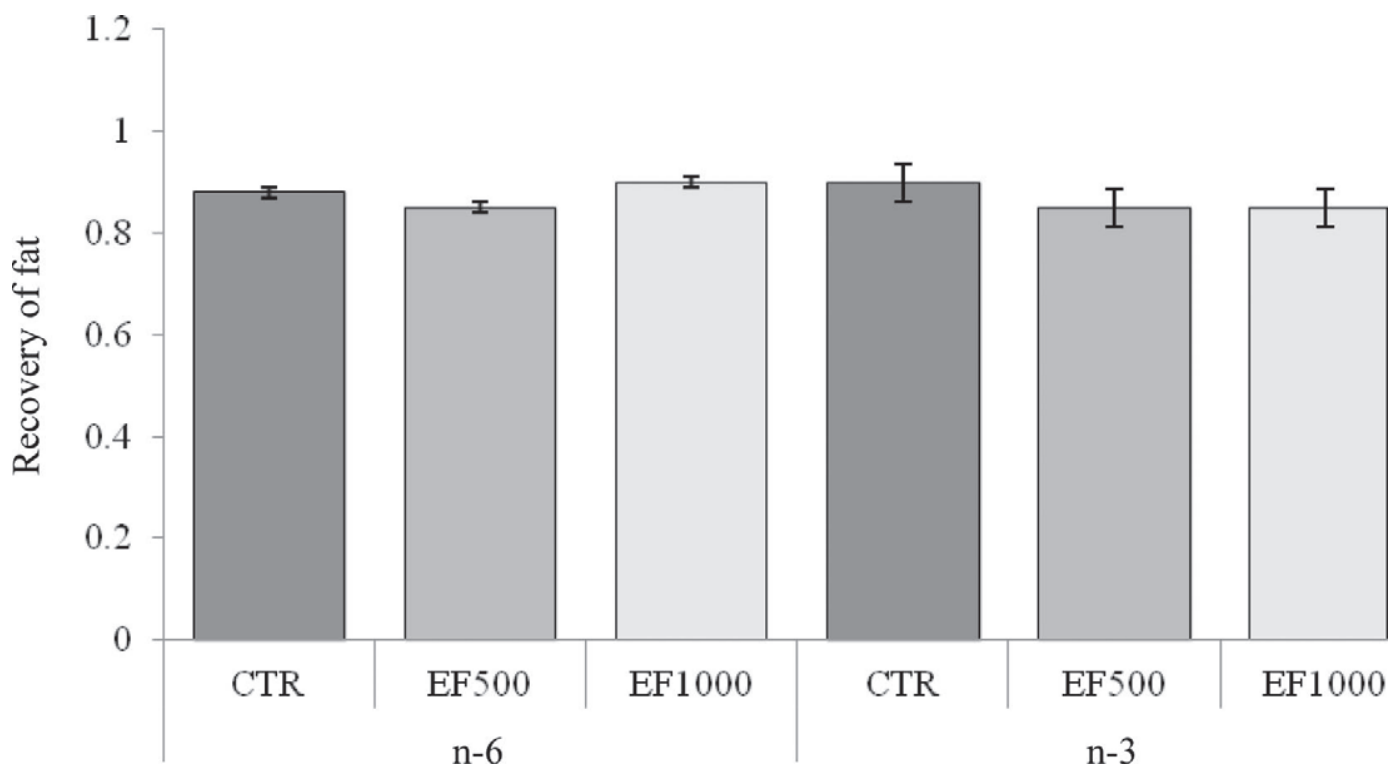

Figure 4. Least squares means (with SE whiskers) of the recovery of $n-6$ and $n-3$ FA from milk to ripened cheese (90 d) produced by cows fed the 3 dietary treatments (CTR, EF500, and EF1000 $=0,500$, or 1,000 g/d of extruded flaxseed, respectively). The contrasts between CTR and (EF500 + EF1000) and between EF500 and EF1000 were not significant.

n-3 FA, is remarkable from a nutritional point of view, as the intake of these FA is recommended by human nutritionists to minimize the risk of cancer and cardiovascular diseases (Simopoulos, 1996). Similar results were reported by Bailoni et al. (2004), who studied the effects on FA profile of cow milk due to the replacement of soybean meal with full-fat extruded or toasted soybean seeds.

\section{Effect of EF on FA Profile of Ripened Cheese}

To date, few experiments have addressed the effects of flaxseed supplementation on the FA profile of cheese. Moreover, most of these studies have focused on sheep cheese (Luna et al., 2005; Gómez-Cortés et al., 2009; Mele et al., 2011; Mughetti et al., 2012) whereas, to our knowledge, only Dhiman et al. (1999) analyzed the FA profile of cow cheese. The proportions of single FA found in the present study confirmed the data reported for French cheeses (Lucas et al., 2006). Supplementation of dairy cow diets with EF made it possible to increase the nutritional value of ripened cheese through enrichment with n-3 FA (especially C18:3n-3) and a reduction of ratio between n- 6 and n- 3 FA. Results of the present trial are in accordance with other studies conducted on cow (Dhiman et al., 1999) and sheep cheese (Nudda et al., 2005; Gómez-Cortés et al., 2009). As reported for milk, such changes in FA profile would improve the nutritional value of cheese fat (Simopoulos, 1996). However, the FA profile of cheese is not identical to that of milk.

\section{Recovery of Fat, Individual FA, and Groups in Ripened Cheese}

Fat recovery in cheese for fresh and short-ripened cheeses is often about $90 \%$ of fat present in processed milk (Cipolat-Gotet et al., 2013) and it depends almost exclusively on fat loss in whey. In ripened cheese matured for a long time, recovery can be substantially less depending on microbial and enzymatic activity during ripening (Summer et al., 2003). To date, no information is available on fat recovery in ripened cheese produced from milk of cows fed oilseeds. Results of the current experiment provided evidence that the presence of $\mathrm{EF}$ in dairy cow diets did not affect the transfer of fat from milk to ripened cheese. In this regard, the literature indicates that fat recovery is affected by several factors such as the cheese-making process, season, farming conditions, and feeding regimen (Summer et al., 2003). In the present study, the cheese-making process, season, and farming conditions were the same for all experimental groups, which could explain the lack of notable effects on fat recovery. It is largely recognized that, during ripening, fat cheese is subjected to lipolysis due to the activity of the endogenous lipoprotein lipase (LPL) contained in milk, and to the possible inoculation of other enzymes with lipolytic activity, to enhance the development of correct flavor in ripened cheese (Collins et al., 2003). The LPL is generally very active, even if the activity of this enzyme can be reduced when high cooking temperatures are used (Collins et al., 2003). Several authors agree that the extent of lipolysis 
in cheese can vary depending on the composition of original milk, the cheese-technology procedure, and the type of ripening (McSweeney, 2007a). As regards the cheese-making process, cheeses produced using raw milk, as in the present study, are usually subjected to a more extensive lipolysis than those prepared from pasteurized milk, as pasteurization deactivates LPL (McSweeney, 2007b). Recently, Buccioni et al. (2012) produced Pecorino Toscano using raw milk fortified with a starter culture of lactic acid bacteria and observed some changes in the FA profile of cheese during ripening $(60 \mathrm{~d})$, as the content of stearic acid increased, whereas that of $\mathrm{C} 18: 1$ and conjugated linoleic acid tended to decrease. In the current experiment, we could speculated that LPL was the primary agent of lipolysis, because cheese was manufactured from raw milk and the cheese-making procedure did not involve the use of enzymes promoting lipolysis. The reasons underlying the lesser recovery of short-chain FA compared with medium- and long-chain FA are unclear. Collins et al. (2003) reported that, during ripening, short-chain FA should be generated as result of lipolysis, thus their relative concentrations would be increased. However, short-chain FA could also be catabolized to flavored compounds (methyl ketones, thioesters, and lactones), thus their proportion in cheese could decrease in relation to the original milk. In the current experiment, most of the FA showed a recovery close to that of fat. In the case of C4:0, the very low level of recovery could be attributed to the fact that this FA, being volatile, can be lost during ripening and sample preparation for GC analysis. Moreover, separation and the extraction of short-chain FA are more difficult compared with those of other FA, and the measurements obtained for these FA could be less reliable (IDF, 1991). These arguments are supported by the large variability observed for values of C4:0, especially in milk samples (SEM $=0.436)$.

Regarding the very high relative recovery observed for C18:3n-6, it is clear that it was not affected by the flaxseed supplementation of diet and did not follow the trend observed for linolenic acid (C 18:3n-3) in milk and in cheese.

\section{CONCLUSIONS}

The results of the present study confirm that feeding cows with flaxseed allows the production of dairy products with a more favorable FA profile through an increase in n-3 FA proportion in both milk and cheese. In this regard, the dietary inclusion of $500 \mathrm{~g} / \mathrm{d}$ of extruded flaxseed seems to be sufficient for a more favorable FA profile. The presence of extruded flaxseed in dairy cow diets did not influence fresh cheese yield or the percentage of fat recovery in cheese after $90 \mathrm{~d}$ of ripening, irrespective of supplementation level of flaxseed (500 or $1,000 \mathrm{~g} / \mathrm{d}$ ). On average, the recovery of individual milk fatty acids in cheese was similar to that of total fat, with some notable exceptions for short-chain SFA (lower recovery) and for C18:3n-6 (higher recovery). However, the role and incidence of lipolysis on the recovery of short-chain FA in ripened cheese need to be better investigated and clarified.

\section{ACKNOWLEDGMENTS}

Authors are grateful to Alberto Simonetto and Luca Grigoletto [Department of Agronomy, Food, Natural Resources, Animals and Environment (DAFNAE), University of Padova, Legnaro (PD), Italy] for their skilled technical support, to Nicola Cologna (CONCAST, Trento, Italy) and Claudio Cipolat-Gotet (DAFNAE) for their cheese-making activities, and to Massimo De Marchi and Alessio Cecchinato (DAFNAE) for their scientific support.

\section{REFERENCES}

AOAC International. 2003. Official Methods of Analysis. 17th ed. AAOAC International, Arlington, VA.

Bailoni, L., A. Bortolozzo, R. Mantovani, A. Simonetto, S. Schiavon, and G. Bittante. 2004. Feeding dairy cows with full fat extruded or toasted soybean seeds as replacement of soybean meal and effects on milk yield, fatty acid profile and CLA content. Ital. J. Anim. Sci. 3:243-258.

Bailoni, L., G. Prevedello, S. Schiavon, R. Mantovani, and G. Bittante. 2005. CLA content and n-3/n-6 ratio in dairy milk as affected by farm size and management. Pages 333-338 in Indicators of Milk and Beef Quality. J. F. Hocquette, and S. Gigli, ed. EAAP, Rome, Italy.

Banks, J. M. 2007. Cheese yield. Pages 102-104 in Cheese Problems Solved. P. L. H. McSweeney, ed. Woodhead Publishing Ltd., Cambridge, UK.

Banks, J. M., L. J. Clapperton, D. D. Muir, and A. K. Girdler. 1986. The influence of diet and breed of cow on the efficiency of conversion of milk constituents to curd in cheese manufacture. J. Sci. Food Agric. 37:461-468.

Bittante, G., C. Cipolat-Gotet, and A. Cecchinato. 2013. Genetic parameters of different measures of cheese yield and milk nutrient recovery from an individual model cheese-manufacturing process. J. Dairy Sci. 96:7966-7979.

Bittante, G., M. Penasa, and A. Cecchinato. 2012. Invited review: Genetics and modeling of milk coagulation properties. J. Dairy Sci. 95:6843-6870.

Bouchard, J., E. Chornet, and R. P. Overend. 1988. High-performance liquid chromatographic monitoring carbohydrate fractions in partially hydrolyzed corn starch. J. Agric. Food Chem. 36:1188-1192.

Buccioni, A., S. Minieri, G. Conte, D. Benvenuti, A. Pezzati, M. Antongiovanni, S. Rapaccini, and M. Mele. 2012. Changes in conjugated linoleic acid and C18:1 isomers profile during the ripening of Pecorino Toscano cheese produced with raw milk. Ital. J. Anim. Sci. 11:426-430.

Chouinard, P. Y., L. Corneau, D. M. Barbano, L. E. Metzger, and D. E. Bauman. 1999. Conjugated linoleic acids alter milk fatty acid composition and inhibit milk fat secretion in dairy cows. J. Nutr. 129:1579-1584.

Christie, W. W. 1982. A simple procedure for rapid transmethylation of glycerolipids and cholesteryl esters. J. Lipid Res. 23:1072-1075. 
Cipolat-Gotet, C., A. Cecchinato, M. De Marchi, and G. Bittante. 2013. Factors affecting variation of different measures of cheese yield and milk nutrient recovery from an individual model cheesemanufacturing process. J. Dairy Sci. 96:7952-7965.

Collins, Y. F., P. L. H. McSweeney, and M. G. Wilkinson. 2003. Lipolysis and free fatty acid catabolism in cheese: A review of current knowledge. Int. Dairy J. 13:841-866.

Cologna, N., R. Dal Zotto, M. Penasa, L. Gallo, and G. Bittante. 2009. A laboratory micro-manufacturing method for assessing individual cheese yield. Ital. J. Anim. Sci. 8:393-395.

Dhiman, T. R., E. D. Helmink, D. J. McMahon, R. L. Fife, and M. W. Pariza. 1999. Conjugated linoleic acid content of milk and cheese from cows fed extruded oilseeds. J. Dairy Sci. 82:412-419.

Fagan, C. C., M. Castillo, F. A. Payne, C. P. O'Donnell, M. Leedy, and D. J. O'Callaghan. 2007. Novel online sensor technology for continuous monitoring of milk coagulation and whey separation in cheesemaking. J. Agric. Food Chem. 55:8836-8844.

Glasser, F., A. Ferlay, and Y. Chilliard. 2008. Oilseed lipid supplements and fatty acid composition of cow milk: A meta-analysis. J. Dairy Sci. 91:4687-4703.

Gnädig, S., J. F. Chamba, E. Perreard, S. Chappaz, J. M. Chardigny, R. Rickert, H. Steinhart, and J. L. Sebedio. 2004. Influence of manufacturing conditions on the conjugated linoleic acid content and the isomer composition in ripened French Emmental cheese. J. Dairy Res. 71:367-371.

Gómez-Cortés, P., A. Bach, P. Luna, M. Juárez, and M. A. de la Fuente. 2009. Effects of extruded linseed supplementation on n-3 fatty acids and conjugated linoleic acid in milk and cheese from ewes. J. Dairy Sci. 92:4122-4134.

Gonthier, C., A. F. Mustafa, D. R. Ouellet, R. Berthiaume, and H. V. Petit. 2005. Feeding micronized and extruded flaxseed to dairy cows: Effects on blood parameters and milk fatty acid composition. J. Dairy Sci. 88:748-756.

International Dairy Federation. 1991. Determination of free fatty acids in milk and milk products. Bulletin 265. Int. Dairy Fed., Brussels, Belgium.

International Dairy Federation. 1995. International IDF Standard 148A:1995: Milk—Enumeration of somatic cells. Int. Dairy Fed., Brussels, Belgium.

International Dairy Federation. 2000. International IDF Standard 141C:2000: Determination of milk fat, protein and lactose content-Guidance on the operation of mid-infrared instruments. Int. Dairy Fed., Brussels, Belgium.

Janhøj, T., and K. B. Qvist. 2010. The formation of cheese curd. Pages 130-165 in Technology of Cheesemaking. B. A. Law, and A. Y. Tamine, ed. Wiley-Blackwell, Ames, IA.

Kennelly, J. J., and R. G. Khorasani. 1992. Influence of flaxseed feeding on the fatty acid composition of cow's milk. Pages 99-105 in Proc. 54th Flax. Inst. Conf., J. F. Carter, ed. North Dakota State Univ., Fargo.

Kim, Y. K., D. J. Schingoethe, D. P. Casper, and F. C. Ludens. 1991. Lactational response of dairy cows to increased dietary crude protein with added fat. J. Dairy Sci. 74:3891-3899.

Lucas, A., E. Rock, J. F. Chamba, I. Verdier-Metz, P. Brachet, and J. P. Coulon. 2006. Respective effects of milk composition and the cheese-making process on cheese compositional variability in components of nutritional interest. Lait 86:21-41.

Lucey, J., and J. Kelly. 1994. Cheese yield. J. Dairy Technol. 47:1-14.

Luna, P., J. Fontecha, M. Juarez, and M. A. de la Fuente. 2005. Changes in the milk and cheese fat composition of ewes fed commercial supplements containing linseed with special reference to the CLA content and isomer composition. Lipids 40:445-454.

Macciotta, N. P. P., A. Cecchinato, M. Mele, and G. Bittante. 2012. Use of multivariate factor analysis to define new indicator variables for milk composition and coagulation properties of Brown Swiss cows. J. Dairy Sci. 95:7346-7354.

Martin, B., D. Pomies, P. Pradel, I. Verdier-Metz, and B. Remond. 2009. Yield and sensory properties of cheese made with milk from Holstein or Montbeliarde cows milked twice or once daily. J. Dairy Sci. 92:4730-4737.
Martin, C., J. Rouel, J. P. Jouany, M. Doreau, and Y. Chilliard. 2008. Methane output and diet digestibility in response to feeding dairy cows crude linseed, extruded linseed, or linseed oil. J. Anim. Sci. $86: 2642-2650$.

McSweeney, P. L. H. 2007a. How does flavour develop in cheese during ripening? Pages 191-193 in Cheese Problems Solved. Woodhead Publishing Limited, Cambridge, UK.

McSweeney, P. L. H. 2007b. What effects does pasteurisation have on cheesemilk? Pages 22-23 in Cheese Problems Solved. Woodhead Publishing Limited, Cambridge, UK.

Mele, M., G. Contarini, L. Cercaci, A. Serra, A. Buccioni, M. Povolo, G. Conte, A. Funaro, S. Banni, G. Lercker, and P. Secchiari. 2011. Enrichment of Pecorino cheese with conjugated linoleic acid by feeding dairy ewes with extruded flaxseed: Effect on fatty acid and triglycerides composition and on oxidative stability. Int. Dairy J. $21: 365-372$.

Mertens, D. R. 2002. Gravimetric determination of amylase-treated neutral detergent fiber in feeds with refluxing in beakers or crucibles: Collaborative study. J. AOAC Int. 85:1217-1240.

Mughetti, L., F. Sinesio, G. Acuti, C. Antonini, E. Moneta, M. Peparaio, and M. Trabalza-Marinucci. 2012. Integration of extruded linseed into dairy sheep diets: Effects on milk composition and quality and sensorial properties of Pecorino cheese. Anim. Feed Sci. Technol. 178:27-39.

NRC. 2001. Nutrient Requirements of Dairy Cattle. 7th rev. ed. Natl. Acad. Press, Washington, DC.

Nudda, A., G. Battacone, M. G. Usai, S. Fancellu, and G. Pulina. 2006. Supplementation with extruded linseed cake affects concentrations of conjugated linoleic acid and vaccenic acid in goat milk. J. Dairy Sci. 89:277-282.

Nudda, A., M. A. McGuire, G. Battacone, and G. Pulina. 2005. Seasonal variation in conjugated linoleic acid and vaccenic acid in milk fat of sheep and its transfer to cheese and Ricotta. J. Dairy Sci. 88:1311-1319.

Petit, H. V. 2003. Digestion, milk production, milk composition, and blood composition of dairy cows fed formaldehyde treated flaxseed or sunflower seed. J. Dairy Sci. 86:2637-2646.

Petit, H. V., C. Germiquet, and D. LeBel. 2004. Effect of feeding whole unprocessed sunflower seeds and flaxseed on milk production, milk composition, and prostaglandin secretion in dairy cows. J. Dairy Sci. 87:3889-3898.

Pezzi, P., M. Giammarco, G. Vignola, and N. Brogna. 2007. Effects of extruded linseed dietary supplementation on milk yield, milk quality and lipid metabolism of dairy cows. Ital. J. Anim. Sci. 6:333-335.

Politis, I., and K. F. Ng-Kwai-Hang. 1988. Association between somatic cell count of milk and cheese-yielding capacity. J. Dairy Sci. $71: 1720-1727$.

SAS Institute. 2005. User's Guide: Statistics. SAS Institute Inc., Cary, NC.

Shingfield, K. J., Y. Chilliard, V. Toivonen, P. Kairenius, and D. I. Givens. 2008. Trans fatty acids and bioactive lipids in ruminant milk. Pages 3-65 in Bioactive Components of Milk: Advances in Experimental Medicine and Biology. Vol. 606. Z. Bösze, ed. Springer, New York, NY.

Simopoulos, A. P. 1996. Omega-3-fatty acids and public health. Pages 5-28 in Proc. Flax Council of Canada Conf.: Flax, the Next Decade.

Summer, A., P. Franceschi, A. Bollini, P. Formaggioni, F. Tosi, and P. Mariani. 2003. Seasonal variations of milk characteristics and cheesemaking losses in the manufacture of Parmigiano-Reggiano cheese. Vet. Res. Commun. 27:663-666.

Verdier-Metz, I., J. B. Coulon, and P. Pradel. 2001. Relationship between milk fat and protein contents and cheese yield. Anim. Res. 50:365-371.

Zicarelli, L., A. Potena, M. Di Rubbio, A. Coletta, C. Caso, B. Gasparrini, and R. Di Palo. 2007. Estimation of buffalo cheese yield by using the chemical-physical parameters of the milk. Ital. J. Anim. Sci. 6:1100-1103 